pupillary margin of the iris, leaving the periphery intact, in cases where the central opacity in the lens is stationary, and where vision is improved by dilatation of the pupil. The operation had been performed in three cases with great success in Quaglino's clinic, and is considered preferable to iridectomy, and in many cases to extraction or discision. It is suggested that it might also be a more satisfactory method than that of iridectomy of treating some cases of nebula of the cornea. There is no danger of prolapse of the iris if eserine be used energetically immediately after the operation. The operation is by no means novel.

Total Sympblepharon of Upper and Lower Eyelids of вотн Exes.-A remarkable case of this nature occurred in the practice of Dr Keyer of Philadelphia (Klin. Monatsblätter, November 1880). The patient, a man 43 years of age, had suffered from inflammation of the conjunctiva, probably membranous, eighteen months before applying for advice. Shortly after the beginning of the conjunctivitis he was confined to bed for seven weeks with inflammation of the lungs. During this serious illness the condition of the eye does not seem to have received any attention, and the patient lay for a long time with his eyes closed, the result being that the lids of both eyes became adherent to the eyes, and the patient was only able to distinguish light from darkness, and had to be led about the streets. As the membrane growing to the cornea was somewhat flaccid, and admitted of stretching, an operation was decided upon, and by carefully tearing and dissecting it off the corner of the left eye, this was left totally clear, so that the iris could be distinctly seen. For long, however, the patient was unable to close his eye. At present, two years after the operation, he has thoroughly regained the power over his lids, and can count fingers at $10^{\prime}$ and get about everywhere alone. The right eye does not appear to have been operated on. This case is probably unique.

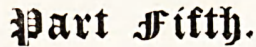

\section{MEDICAL NEWS.}

Colchester Idiot Asylum.-We are informed that there are two points of difference between the Earlswood and Colchester asylums, which are held to account for the greater average mortality in the latter than in the former asylum, viz., that only hopeful cases are admitted upon the Earlswood election-list, and the age must not exceed 16 years, whereas at Colchester hopeless as well as hopeful cases are eligible, and at all ages.

Burroughs, Wellcome, \& Co., chemists, London, have sent us specimens of some of their recent preparations, including "Beef and Iron Wine," "Fellows' Compound Syrup of the Hypophosphites," "The Kepler Improved Malt Extract," "Wyeth's Dialysed Iron," 
“Wyeth's Peptonic Tablets," “Wyeth's Chlorate of Potash and Chloride of Ammonia Tablets." 'These "tablets" are certainly very pretty objects to look at, but this is their chief recommendation. The other preparations are excellent, and we have much pleasure in recommending them to the notice of the profession. There has also been sent a specimen of "Lawton's Absorbent Cotton," which we recommend to the favourable consideration of surgeons and gynæcologists.

\section{OBITUARY.}

\section{DR ANDREW WOOD.}

JUST on going to press we have with much regret to record the sudden death of this eminent man, well known to all our readers as occupying a high position in the medical world, both as physician, man of letters, and medical legislator. We hope to lay before our readers a more extended notice of his life and character in our next number.

\section{PUBLICATIONS RECEIVED.}

F. BARnes, M.D.,-German-English Dictionary of Words and Terms used in Medicine and its Cognate Sciences. $H$. K. Lewis, Lond., 1881.

W. Braithwaite, M.D., and James BraithwaITe, M.D.,-Retrospect of MedicineVol. LXXXI. Simpkin, Marshall, \& Co., Lond., 1880.

J. E. Burton, L.R.C.P., - Handbook of Midwifery for Midwives. J. \& $\mathbf{A}$. Churchill, Lond., 1880.

R. E. Carrington, M.D.,-Manual of Dissections of the Human Body. George Bell \& Sons, Lond., 1881.

A. H. Carter, M.D.,-Elements of Practical Medicine. H. K. Lewis, Lond., 1880.

John Cleland, M.D., F.R.S.,-Evolution, Expression, and Sensation. James Maclehose, Glasgow, 1881.

Walter J. Coulson, F.R.C.S.,-Diseases of the Bladder and Prostate Gland. J. \& A. Churchill, Lond., 1881.

D. H. Cullimore,-Consumption as a Contagious Disease. Baillière, Tindall, \& Cox, Lond., 1880.

Surgeon-General J. M. Cuningham, M.D,Report on the Cholera Epidemic of 1879 in Northern India.

Charles Denison, A.M., M.D.,- Rocky Mountain Health Resorts. Houghton, Mifflin, \& Co., Boston, 1881.

J. Mirner Fotherails, M.D.,-Food for the Invalid, etc. Macmillan \& Co., Lond., 1880.

A. L. Galabin, M.A., M.D.,-Student's Guide to the Diseases of Women. J. \& A. Churchill, Lond., 1881.

R. Harrison, F.R.C.S., - The Surgical Disorders of the Urinary Organs. J. \& A. Churchill, Lond., 1880.
J. Pearson Irvine, M.D., - Relapse of Typhoid Fever. J.\& A. Churchill, Lond., 1880.

E. Klein, M.D., and E. Noble Smith, L.R.C.P.-Atlas of Histology. Part 13. Smith, Elder, \& ('o., Lond., 1880.

Henry G. Landis, A.M., M.D.,-How to Use the Forceps. E. B. Treat, New York, 1880.

James R. LAne, F.R.C.S.,-Lectures on Syphilis. J. \& A. Churchill, Lond., 1881.

F. W. Levander, - Solutions of Questions in Magnetism and Electricity. H. K. Lewis, Lond., 1880.

Onderzoekingen gedaan in het Physiologisch Laboratorium derUtrechtscheHoogeschool. Derde Reeks. V.3de Aflevering. W. F. Dannenfelser, Utrecht, 1880.

H. Sinclair Paterson, M.D.,- Health Studies. Hodder \& Stoughton, Lond., 1880.

Dr W. H. Schussler,-Abridged Therapeutics. Elliot Stock, Lond., 1880.

Transactions of the American Otological society. Vol. II. Part 4. A. Williams \& Co., Boston, 1880.

Transactions of the Clinical Society of London. Vol. XIII. Longmans, Green, \& Co., Lond., 1880.

Transactions of the Pathological Society of London. Vol. XXXI.

Jos. H. WARren, M.D.,-Hernia, Strangulated and Reducible. Sampson Low, Marston, Searle, \& Rivington, Lond., 1880.

Joseph Wilson, M.D., - Drainage for Health. Presley Blakiston, Philadelphia, 1881.

Ziemssen's Cyclopædia of the Practice of Medicine. Vol. IX. Sampson Low, Marston, Searle, \& Rivington, Lond., 1880. 